\title{
THE ANGLO-BOER WAR IN THE BORDERLANDS OF THE TRANSVAAL AND ZULULAND, 1899-1902
}

\author{
Prof Johan Wassermann \\ History Education, Faculty of Education \\ University of KwaZulu-Natal
}

\begin{abstract}
The low intensity warfare in the borderlands of the Transvaal and Zululand during the Anglo-Boer War is, despite lasting for the duration of the war, a neglected area in the historiography of the conflict. This article, which employs the conceptual framework of borderlands, attempts to address this. In doing so, the conflict, the way it transcended the geography of the region and the way it impacted on all the inhabitants of the area, are investigated. In the process, the nature of the conflict, which for the most part centred on the raiding of livestock in addition to attacks and raids on homesteads, farms, isolated shops and outlying military and government posts, is laid bare. The final outcome of the war in this area was the dismantling of the borderlands of the Transvaal and Zululand in favour of the Colony of Natal.
\end{abstract}

\section{Introduction}

One of the neglected areas in the history of the Anglo-Boer War is the conflict along the borderlands of the South African Republic (Transvaal) and Zululand. Although Maphalala ${ }^{1}$ has researched the Anglo-Boer War in this region, his point of departure has invariably been an ethnocentric one which exclusively foregrounded Zulu experiences. Minnaar, ${ }^{2}$ in turn, chose to focus on the war in Zululand as a geographically closed system. Neither of these historians, nor any of the standard reference works on the Anglo-Boer War, ${ }^{3}$ have explored the war across the extended Transvaal-Zululand border, which stretched from the Tugela River in

Scientia Militaria, South African Journal of Military Studies,

Vol 39, Nr 2, 2011, pp. 25-51. doi: $10.5787 / 39-2-111$ the south to the Pongola River in the north and to the Buffalo, Blood and Lynspruit Rivers in the west in any detail.

The conceptual framework for this article is borderlands, which can be defined as 
areas at the periphery of a country or territory, where cultural and natural phenomena overlap. ${ }^{4}$ The Transvaal-Zululand border area was such an area for, as a very porous border that was greatly unregulated by the central authorities, the movement of people, livestock, ideas and goods happened in an unregulated manner along a series of wagon roads and footpaths between Vryheid on the Transvaal side and Eshowe on the Zululand side. This borderland came into being when, in the aftermath of the Anglo-Zulu War of 1879, Britain embarked on a process to destroy the Zulu kingdom. A consequence of this was the civil war between King Cetshwayo and Zibhebhu ${ }^{5}$ from which the latter emerged victorious. Cetshwayo eventually died in 1884 in Eshowe, most likely of poisoning, while under the protection of the resident magistrate. ${ }^{6}$

Cetshwayo was succeeded by his son Dinizulu who had to find a way forward. This he did by forming an alliance with Boers from the Transvaal who had for decades invaded western Zululand for grazing. ${ }^{7}$ In an attack by the combined forces of Dinizulu and his Boer allies under the command of Lucas Meyer and which also included a young L.J. (Louis) Botha, Zibhebhu and his followers were soundly defeated on 5 June 1884. However, although this victory strengthened the position of Dinizulu, his alliance with the Boers came at a price as 2700000 acres of land populated by loyal followers had to be ceded. On this land, the Boers formed the New Republic with Vryheid as its capital and Lucas Meyer as the President. When the Boers claimed even more land and the right to a protectorate over Dinizulu, the British intervened by recognising, in October 1886, the New Republic. In turn, the right to a protectorate over Dinizulu and claims to an area known as Proviso B were dropped by the Boers on condition that those who had settled in that area retain their farms. Protests by Dinizulu ${ }^{8}$ and his followers fell on deaf ears and Britain responded by annexing Zululand, including Proviso B, and turning it into the British Colony of Zululand. The geopolitical manoeuvring was concluded when the New Republic was, in 1887, absorbed into Transvaal, making all inhabitants Republican subjects ${ }^{9}$ and when Zululand was annexed to the Colony of Natal in 1898. ${ }^{10}$ The borderlands, in which the Anglo-Boer War events to be covered in this article occurred, were thus in place.

Demographically the inhabitants of the Transvaal side (Vryheid district) of the borderlands consisted of Zulu people who resided on farms created during the formation of the New Republic, ${ }^{11}$ and white inhabitants who generally also resided on farms acquired at the time. On the Zululand side of the border, the population was almost exclusively Zulu. The few white inhabitants of Zululand were traders, opportunists, Afrikaner residents of Proviso B or Natal colonial officials. The annexation of Zululand to Natal meant that all inhabitants were subjects of both 
Natal and the British Empire. ${ }^{12}$

The purpose of this article, in the light of the above, is to provide a comprehensive account, which transcends ethnocentrism and a narrow geography, of the low intensity warfare carried out along the geopolitical area that constituted the borderlands of Transvaal and Zululand. In doing so, it is envisaged that this boundary history will make a contribution to a neglected area of the military history of the Anglo-Boer War.

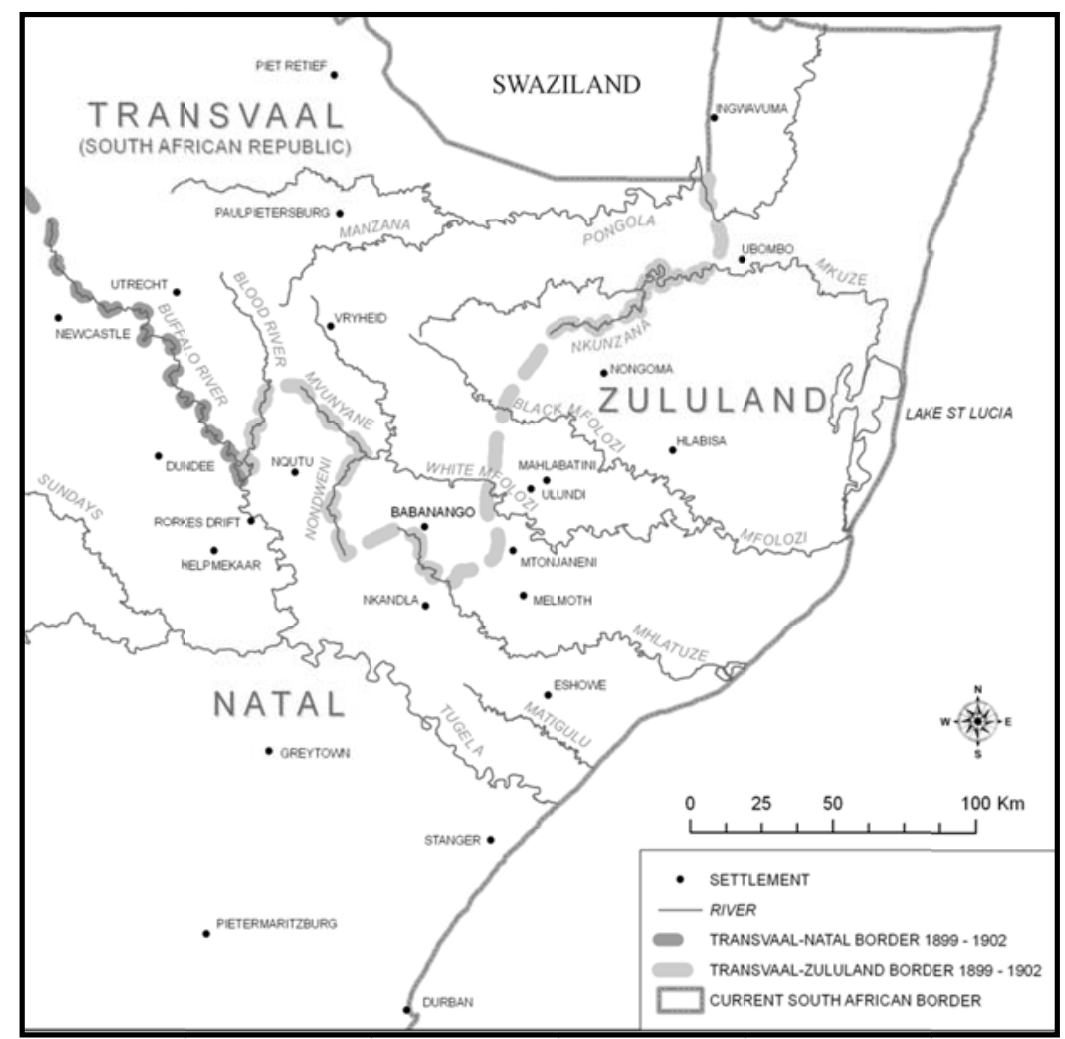

Map 1: Transvaal-Zululand Borderlands (1899-1902)

The pre-war positioning of the population of the Transvaal-Zululand borderlands 
It is important to understand the position within which the population of the borderlands found themselves with war clouds gathering. The situation of the white population of Transvaal was fairly clear - white male subjects between the ages of 16 and 60 were legally eligible for commando duty and thus for direct operational involvement in the war. Whites residing in Zululand, as British subjects, could not be conscripted into the war in such a direct manner but were free to join volunteer regiments if they wished to do so. ${ }^{13}$ The position of the majority of the African population was, however, different. As far as the Boers were concerned, with reference to the Transvaal-Zululand borderlands, it was important to remain on a good footing with the Zulus so as not to fight on an additional front. Owing to their numerical superiority and imagined military tradition, the Zulus could prove to be a formidable adversary, capable of playing a decisive role in the conflict. To avoid this, General Coenraad Meyer of Vryheid conveyed a personal message to Dinizulu, who was then still viewed by the Boers and many Zulus on both sides of the border as the Zulus' de facto leader, calling on him not to take part in the coming "white man's war". ${ }^{14}$

In contrast, the authorities in the Vryheid district did not pay the same attention to the Zulus who were resident on farms which formed part of the Zulu kingdom prior to the creation of the New Republic some 15 years earlier. Some of these people were unhappy with their plight as farm labourers and tenants and many among them viewed the outbreak of war as an opportunity to regain their ancestral land. ${ }^{15}$ Others used the outbreak of war to flee across the border into Zululand in order to escape their treatment and the tension that existed on the Transvaal side of the border. ${ }^{16}$ Generally speaking, in the view of Pretorius, relationships in the Boer Republics between Africans and Boers at the time of the Anglo-Boer War were not very good. ${ }^{17}$

The Natal government, white Natalians, and the imperial government within the pre-war context, held the same view as the Boer Republics, namely that the Anglo-Boer War was to be a "white man's war". ${ }^{18}$ The rationale behind this kind of racial thinking was best expressed by the Prime Minister of Natal, Colonel Albert (A.H.) Hime: “... employment of natives ... would be in opposition to the generally acknowledged trend of colonial public opinion, and would ultimately lead to the lessening of the prestige of the white man, and of the natives' respect for the British government." ${ }^{19}$ It was furthermore feared that participation in the war could lead to a general uprising among Africans against the Colony of Natal and its white inhabitants. $^{20}$

Support for Hime came from Attorney General Henry Bale who was 
adamant that Natal Africans should not be involved in the war against the Boer Republics, except when they were defending their cattle from "extensive looting". He feared that once armed they could rise up and kill white women and children. ${ }^{21}$ Bale's fears were echoed by white residents from Dundee, ${ }^{22}$ Weenen, Kranskop, Melmoth and Newcastle, and also received support from newspapers such as the Times of Natal $^{23}$ and the Natal Witness. ${ }^{24}$ Consequently, to allay the fears of white Natalians and to keep African subjects in place, Prime Minister Hime issued, via the various magistrates, the following instruction to the different chiefs (amakosi) and headmen (izinduna):

That in the event of war breaking out between the English and the Dutch, the Queen wishes the Natives to remain within their own borders, as the war will be a white man's war, but they may, of course, protect themselves and their property against attack or seizure by the enemy.

It was also stressed that magistrates were to limit themselves to this declaration and under no circumstances was any other information to be provided without the instructions of the Natal government. ${ }^{25}$ Thus, in line with the racial thinking of the time, and so as to maintain internal political stability, the Natal government had declared the coming war a "white man's war". ${ }^{26}$

The various Natal magistrates immediately informed both the amakosi and izinduna of the policy. ${ }^{27}$ However, the section of the message relating to the right of the Africans to protect their property and themselves caused much concern, especially among the magistrates of the Natal districts that bordered on the Boer Republics. These magistrates concluded that, based on the instruction, Africans would ask for arms and ammunition. They therefore wanted to know which answer was to be given should an African ask: "How are we to protect ourselves without arms?” After consultation, the Prime Minister, the Colonial Secretary and the Secretary for Native Affairs decided that the most appropriate answer to be given was: “... the necessity for protecting themselves and their property is regarded by the Government as a remote contingency". ${ }^{28}$ With this evasive answer, and completely discounting the possibility that such a situation might arise, the Natal government regarded the matter as settled.

Although the stated policy applied to all Natal Africans, Maphalala argues that, since the former did not constitute a uniform community, the fear aspect that underpinned the instruction was aimed more at the Zulus who resided in Zululand than at their kin who resided in other districts in the Colony. ${ }^{29}$ The basis for this argument was that the residents of Zululand were viewed as a "martial race", ${ }^{30}$ who 
were different from other Natal Africans who were in many cases Christian converts with a tradition steeped in support of the Natal government and the Empire by, for example, fighting during the Anglo-Zulu War of 1879 on the side of the British. ${ }^{31}$ Consequently, an apprehension existed that should Africans be armed and the Boers be defeated, especially those resident in Zululand would lose their fear of British supremacy and rise up to seek revenge for the 1879 war. Thus, when the Anglo-Boer War broke out on 11 October 1899, the magistrates of each of the 11 districts in Zululand reminded the local Zulu amakosi and izinduna to remain within the borders of their reserves, and to refrain from becoming involved in military operations. The only agency allowed was for them to defend, with the support of the Zululand Native Police (Nongqayi), their property from attacks by Boer commandoes. ${ }^{32}$ When the Anglo-Boer War broke out, both the Boer Republics and the Colony of Natal had similar views on African involvement in the conflict in general and specifically along the Transvaal-Zululand border.

However, the position adopted by the Natal government was to a certain extent a disingenuous one. For years prior to the issuing of the instruction as outlined above, Africans were used as spies by the Natal government to gather information. These "Native Intelligence Officers", who were employed by the Secretary of Native Affairs (SNA), F.R. Moor, reported their information either to the magistrates or directly to the SNA. ${ }^{33}$ Structurally, a system of intelligence gathering thus existed that continued, when war broke out, to gather information including about the war along the Transvaal-Zululand border. ${ }^{34}$ To the Natal government, spying must have been viewed, alongside other auxiliary services, as falling outside of the ambit of the instruction on a "white man's war". This would in turn explain the unwillingness of the Natal government to arm Zulu spies operating in the borderlands.

\section{Militarising the Transvaal-Zululand borderlands - British and Boer defensive strategies (October 1899-May 1900)}

The instruction by the Natal government to the Zululand magistrates regarding the wartime position the local populace should adopt was underpinned by a broad defensive plan which served to undermine the order given. As a first step, the Zululand Native Police were strengthened by the recruitment of 500 new members. The task of these men, generally armed with knobkerries and assegais, was to patrol the Transvaal-Zululand border. What made the difficult task of this small force even harder was that their headquarters at Eshowe was not in heliograph communication with the magistracies where they were stationed, namely Nkandla, Nqutu, Ubombo, Nongoma and Melmoth. ${ }^{35}$ Secondly, it was decided that both 
Melmoth and Nkandla would be difficult to defend against a Boer invasion. The Zululand Native Police at these posts were therefore instructed, at the first signs of danger, to retire to Eshowe and Nqutu respectively. Those at Mahlabatini were to go to the magistracy of Nongoma which would, if necessary, be reinforced from Hlabisa. In the northern section of the border, the detachment of Zululand Native Police at Gwaliweni was to congregate at Ingwavuma. At Eshowe, apart from the garrison, a strong detachment of the Zululand Native Police was also kept in reserve so as to be deployed in any direction, but especially towards Melmoth, in case of a Boer invasion. ${ }^{36}$ However, tension existed between the broad defensive plan for Zululand, the position of the Natal Government on African involvement in the war and the reality on the ground. In this regard, the magistrate for Mahlabatini, C.A. Wheelwright, requested that if no regular police could be spared for his district then at least arms and ammunition be supplied so as to allow him to enlist and arm trustworthy Zulus from the district. This was not sanctioned. ${ }^{37}$

This defensive plan for Zululand was based on two factors: Firstly, to the Natal government, the Chief Magistrate and Chief Commissioner (hereafter CM and CC) of Zululand, Sir C.R. (Charles) Saunders ${ }^{38}$ and the British army, the possibility of Boer commandoes crossing the Transvaal-Zululand border with the intention of attacking Eshowe and then Pietermaritzburg or Durban did not exist. Secondly, at least in the view of Attorney General Bale, there was no regiment to spare for defending Zululand. ${ }^{39}$ Consequently, the Natal government were happy to elevate the Zululand Native Police to the first line of defence along the Transvaal-Zululand border.

In the Vryheid district on the Transvaal side of the border, a different practice was adopted regarding African involvement in the war. Before long commandoes had started to commandeer cattle, horses and labour, from Zulus residing in the Vryheid district, which they were under Transvaal law legally entitled to do. ${ }^{40}$ Thus, by the time war started, the Boer commandoes operating in the Vryheid district, and especially the commando under General Coenraad Meyer, with its headquarters at Vryheid and which patrolled the border up to the Pongola River, had indirectly involved Africans in the conflict in a logistical manner. ${ }^{41}$

However, the physical defence of the Republican side of the borderlands was for the most part not conducted by Boer commandoes but by Afrikaners, all of them British subjects, of the Newcastle district in Northern Natal. These men were conscripted on a ruse that they were compelled to join since an African uprising was possible and because they were now, due to the Republican occupation of their district, Transvaal subjects. The meeting to commandeer them and to elect officers 
from their ranks took place on 29 November $1899 .{ }^{42}$ A week later, they were issued with Mausers, ammunition and bandoliers. ${ }^{43}$ The 127-strong Newcastle Commando thereafter departed via Vryheid to the Black and White Umfolozi Rivers area on the Transvaal-Zululand border. The duty of this commando was to patrol and safeguard the border and to deal with a possible Zulu uprising, ${ }^{44}$ which had, according to unverified rumours that were in line with the deception used to conscript them, already claimed the lives of several white women. ${ }^{45}$

Based on the misinformation about their citizenship status and Zulu actions, the Newcastle Commando assumed its duty. ${ }^{46}$ Cross-border cattle raids, especially by Boers, reciprocated by Zulus, led to further rumours that the latter were preparing to invade the Transvaal. These reports proved to be unfounded and it was even suggested that it was spread by burghers from the Vryheid district who used it as an excuse to remain at home while conscripted British subjects did the military work. ${ }^{47}$ For the most part, the duties of the Newcastle Commando were exclusively that of defence. Despite this, Newcastle Commando t was beset by desertions since its members, as British subjects, were afraid that they would be charged with high treason once the tide of the war had turned against the Republics. ${ }^{48}$ Consequently, strict fines, arrests ${ }^{49}$ and overplaying the possibility of a Zulu uprising were resorted to as measures to keep the Natal Afrikaners on commando. ${ }^{50}$ However, that was as far as members of the Newcastle Commando would participate in the war, and when the Siege of Ladysmith collapsed, its members started to return to the Newcastle district. $^{51}$

The defensive military strategies adopted by the Republics along the Transvaal-Zululand border were completed by the commandoes under Coenraad Meyer and Joachim Ferreira. The former patrolled the Vryheid region while the most westerly reaches of the Transvaal-Zululand border were under the control of Ferreira and his commando. They were stationed at Helpmekaar so as to protect the rear of the Republican army who was at that stage engaging the British army along the Tugela Front. ${ }^{52}$

Challenging the British and Boer defensive military strategies along the Transvaal-Zululand borderlands (October 1899-May 1900)

With clear defensive strategies for the Transvaal-Zululand border drawn up and with conventional warfare along the Tugela River consuming most of the military resources available to both sides and with possible Zulu involvement in the war curbed, the Transvaal-Zululand border reached an impasse. This standoff was, however, from time to time between October 1899 and May 1900, broken by cross- 
border raids and attacks.

The first major incursion into Zululand by a Boer commando was when Commandant Joachim Ferreira and 250 men, on 28 October 1899, cut the telegraph line from Ingwavuma. ${ }^{53}$ Afterwards they looted and burnt down the magistracy and a trading store. The commando then proceeded to take ownership of 500 head of cattle belonging to a local businessman. On 3 November 1899, Ferreira took formal possession of Ingwavuma in the name of the Republics. Following this attack, Magistrate Colenbrander and his staff of 10 white policemen and 25 Zululand Native Policemen fled to the Ubombo Magistracy. ${ }^{54}$

The actions by Ferreira and his commando led Zibhebhu to fear an attack. He therefore had his cattle sent to St. Lucia Bay for safekeeping. This dreaded attack never took place but intimidation, especially by Hendrik Potgieter and his commando, continued along the Transvaal-Zululand border for the remainder of 1899. One of Potgieter's prime duties was to prevent Zulu spies from providing information to the British army and the Zululand magistrates. This was done by warning the local Zulus to stop spying or face the risk of being shot. In response, T.R. Maxwell, the magistrate of Lower Umfolozi, suggested that the spies be armed. However, this was, like previous requests of this nature, refused, citing fear of further retaliation by Boer commandoes as the main reason. ${ }^{55}$

In the light of the activities by the commandoes under Potgieter and Ferreira, rumours arose that a major invasion of Zululand was to take place. Bernard Cressey, a white businessman residing in Zululand, for example, declared that a Natal Afrikaner resident of Proviso B, J.A.F. Ortlepp, had told him that a commando consisting of 600 Boers intended to cross the Transvaal-Zululand border. K.J.D. Ripley equally claimed to have had a conversation with Ortlepp in which the latter had said that he fully expected an attack on Melmoth. ${ }^{56}$ African scouts such as Manlinzela Ka Ngombane, members of the Zululand Native Police and ordinary Africans also fed Magistrate Maxwell with information about the movements of the Afrikaner residents of Proviso B and a possible invasion of Zululand by the Republican forces. ${ }^{57}$ Since much of the information on a possible Boer invasion of Zululand was laced with speculation and rumour, CM and CC Saunders did not pay much attention to it. He did, however, believe that Afrikaner residents of Proviso B were in constant contact with the commandoes and would therefore receive early information of any attack. Such information could, in his view, also be used as an early warning system. ${ }^{58}$ This was especially the case since many a Boer raid into Zululand was guided by former residents of Proviso B who had left Zululand to join the Republican forces. In the Nkandla district, a local shopkeeper, T.W. Cooper, for 
example, recognised several Proviso B Afrikaners in a raiding party. In a later raid, shop-assistant R.J. Hutchinson likewise recognised several Proviso B Afrikaners amongst the raiders. ${ }^{59}$

Rumours of a Boer invasion also abounded in Nqutu and Nkandla, which were located very close to the border with the Vryheid district. As a result, the local Zulus started to worry about the intention of the British military to protect them in case of such an event. Observing the lack of British soldiers in Zululand, the amakosi of Nqutu district informed Magistrate C.F. Hignett that they would defend the area. Hignett did not resist the idea. Putting this plan into action was Mehlokazulu and 250 men who took to guarding the Nqutu Magistracy. Mehlokazulu was, however, unable to stop the Boers from looting the trading stores at Vant's and Rorke's Drift. During a second raid, Tlokoa and his armed followers were able to pursue the Boers from the area, ${ }^{60}$ and in doing so pushed the boundaries of a "white man's war" further back.

The continuous reports of an imminent large-scale Boer invasion of Zululand, coupled with constant cross-border incursions by small Boer commandoes, forced the British army to review their position in the area. From January 1900 onwards, their presence in Zululand was strengthened by the deployment of the Melmoth Field Force, 50 soldiers of the $60^{\text {th }}$ rifles and a troop of Natal Police. Their duty was to help the Zululand Native Police in guarding the Transvaal-Zululand border. These forces were boosted by Colonel Addison and 300 Colonial Scouts who were absorbed into the Melmoth Field Force. This force was in turn strengthened by the arrival of two guns of the Natal Field Artillery and 150 soldiers of the Natal Royal Rifles. ${ }^{61}$ However, not all Zululand residents were happy with the increased military presence in their midst, and especially CM and CC Saunders feared that it would be viewed by the Boers as provocation which would in turn lead to increased raids and even the possible occupation of Zululand. ${ }^{62}$

Beefing up the British forces in Zululand was not in vain, for an invasion was on the cards. The commando under Commandant Joachim Ferreira, stationed at Helpmekaar, and the one under General Coenraad Meyer, with its headquarters at Vryheid, met during January 1900 to plan a large-scale invasion of Zululand. This plan of action was, as predicted by Saunders, based on the strengthening of the British forces in Zululand which made the commandoes fear that it could endanger the rear of the Boer forces fighting along the Tugela Front. ${ }^{63}$ Thus, on 31 January 1900, the long-rumoured Boer invasion of Zululand started when under the leadership of Ferreira a 700-strong commando attacked the Nqutu Magistracy. After a brief skirmish, they captured Magistrate Hignett and his family as well as 50 
Zululand Native Policemen. The commando also took hold of 20 horses, 295 rifles and 65 boxes of ammunition. The attack, and especially the capturing of the Zululand Native Policemen, did not go down well with President Paul (S.J.P.) Kruger of the Transvaal who feared that this incident could lead to a greater Zulu involvement in the war. Consequently, Kruger had the policemen released. The Boers, however, continued to occupy Nqutu since it was strategically useful because it shortened the lines of communication between the Tugela Front and Vryheid considerably. Following this attack, the British army withdrew its forces stationed at Nongoma and Nkandla deeper into Zululand, leaving the Boers with a free hand. While the British army expected the commandoes to capitalise on their successful invasion, this did not take place, and follow-up operations only led to the occupation of the Nkandla Magistracy and the looting of Fry's store. ${ }^{64}$

The occupied magistracies were placed under the control of Field Cornets Potgieter and Van den Berg who tried, after widespread looting had taken place, to restore order. Winning the trust of the local Zulu inhabitants so as to prevent any resistance, was of the utmost importance. To achieve this it was announced that:

- the amakosi and izinduna were to exercise the same authority as before;

- Zululand Native Policemen were to resume their duties;

- compensation claims were to be presented to the field cornets; and

- a hut tax of seven shillings - 50\% less than normal - was to be collected during March 1900.

The occupying forces also allowed the Zulus to share in the spoils of looting and to buy meat and mealies brought in from the Transvaal. Food was also handed to those in need. ${ }^{65}$ In both the Nqutu and Nkandla districts, the message was clear, namely that the area was now occupied by the Republics, and the local Zulu inhabitants were expected to be passive and neutral. ${ }^{66}$ Not all Zulus were taken in by the Boer public relations strategy. Nongamulana fled because he had previously arrested a Boer spy, while Mehlokazulu fled because he was suspected of arming his men to resist the Boer invasion. Sitshitshili, in turn, fled because he had notified Magistrate J.L. Knight of Nkandla of the Boer invasion, which gave the latter time to escape. ${ }^{67}$

The British army reacted swiftly to the invasion of Zululand by means of an incursion across the Transvaal-Zululand border to loot the house and drive off the livestock of a field cornet. To General Louis (L.J.) Botha, by then the Commandant General of the Transvaal forces, this was unacceptable and he was angry that small bands of the British army were allowed to cross the border to loot his home district. Botha, however, received no support for his point of view from General Lucas Meyer, also a resident of the Vryheid district, who viewed the incident as a punitive 
measure for the field cornet's role in an earlier cross-border raid. ${ }^{68}$ These opposing points of view by leading Boer generals on raids across the Transvaal-Zululand border did not argue well for the future of the Boer defence of the Vryheid district.

Once the Boer invasion of Zululand had ended, Dinizulu, in an effort to prevent another Boer attack, provided the British army with spies, scouts and guides to work in both Zululand and the Vryheid district. ${ }^{69}$ As a result, Zulu spies from April 1900 onwards gathered information on the Republican forces across the Transvaal-Zululand border. The Zulu inhabitants of the Vryheid district supported these spies by providing them with information, food and shelter. ${ }^{70}$ From then on, the movements and strengths of the commandoes in this region were better known to the British military than before. On their part, the Boers also actively employed Zulu spies to gain information on British military activities in Zululand. ${ }^{71}$ The earlier reservations held by both sides about involving the majority of the residents of the Transvaal-Zululand borderlands in the war were six months later superseded by the context of the war and the demands for intelligence gathering by people with local knowledge. $^{72}$

By late April 1900, the tide of the war on the Tugela Front was turning against the Republican forces. This, in turn, impacted on the Transvaal-Zululand borderlands in general and on the Vryheid district specifically. The retreating Boer leaders differed on what should happen to the Boer civilians in the Vryheid district. President Paul Kruger wanted them to flee the Vryheid district. However, this was hampered by a lack of available wagons. Most white residents were also not keen to take flight since grazing was scarce on the Highveld. Consequently, Boers from Swaziland and from the Piet Retief and Vryheid districts decided to abandon their farms and to move to Vryheid for protection. Both Generals Lucas Meyer and Louis Botha, supported by President M.T. Steyn of the Orange Free State, deemed this to be the wrong decision and therefore urged Kruger to allow the families to stay on their farms as had been the case in the Orange Free State. Kruger was eventually convinced, and on 18 May 1900, a circular was sent to the Boer commandoes informing them that women and children had to return to the farms and that the men had to return to their commandoes. This instruction placed enormous strain on commando members of the Vryheid district as they were not sure what would happen to their families and property. In the end, these fears proved to be unfounded as women, children and property were generally left untouched by the advancing British army. However, not all families adhered to the instruction and some fled to the Highveld. ${ }^{73}$

The occupation of the Vryheid district by the British army meant that all of 
the borderlands were now under British control. Civilian rule was installed with the appointment of A.J. Shepstone as the local magistrate. ${ }^{74}$ Shepstone, using his institutional knowledge of the spy system operated by the magistrates in Natal and Zululand, with the support of the local military intelligence officer, J. Roberts, immediately set about organising an extensive spy network from among the Zulu inhabitants of the Vryheid district. These spies had to report all Boer movements to Roberts and Shepstone. The difference was, according to Maphalala, that these spies were now all armed with rifles. ${ }^{75}$

Nevertheless, it would be erroneous to argue that all Zulus residing in the borderlands were unsupportive of the Boers, for the relationship between the inhabitants of the area was much more complex. Zulus residing on both sides of the border, for example, took to hiding Boer cattle passing it off as their own. Boer commandoes operating out of the Vryheid district also employed Zulus to purchase foodstuffs from stores in Zululand on their behalf. To counter this, the British army issued a notice under martial law, directing storekeepers not to sell or supply unusual quantities of foodstuffs to Zulus. ${ }^{76}$ Not long after this notice was issued, two Swazis, posing as Zulus, were caught buying goods. They were immediately arrested on suspicion of being Boer collaborators. ${ }^{77}$ Such commercial relationships in the borderlands at times transcended the notion of Boers and British being enemies, and Boer commandoes operating in Zululand were in one instance supplied with provisions in exchange for a horse by Bond and Brodie, two English-speaking British subjects resident in Zululand. ${ }^{78}$

\section{Low-keyed warfare in the Transvaal-Zululand borderlands (June 1900-May} 1902)

With the capitulation of the Republican forces along the Tugela Front and their retreat from the Colony of Natal during May and June 1900, and the subsequent occupation of the Vryheid district by the British army, the war along the border between Zululand and the Transvaal entered a new phase and took on a different dimension. On the Boer side, cross-border guerrilla warfare was punctuated by more conventional military operations culminating in cattle raiding, population displacement and the destruction and looting of property. In turn, the British army operating out of Zululand reciprocated by adopting similar tactics.

One of the first major cross-border events, after the Boers had been driven from Natal, took place when large herds of Boer livestock hidden in Zululand were driven, by order of Major General H.J.T. Hildyard, to Dundee. ${ }^{79}$ This act prompted the commandoes operating out of the Vryheid district to respond by raiding into 
Zululand, taking both moveable and immovable property belonging to the Natal government and local Zulu and English residents. The result of this was that rumours again started to circulate that the Natal Afrikaner stronghold of Proviso B could come under threat. The reason mooted for this was the persistent rumours that the local Afrikaners were collaborating with the Boer commandoes. ${ }^{80}$ Despite the misgivings of CM and CC Saunders, the Afrikaner residents of Proviso B generally cooperated with the authorities by reporting the presence of commandoes in their neighbourhood. D.J. Pretorius, for example, reported to the Melmoth magistrate on two occasions that Boer patrols had visited him on his farm. ${ }^{81}$ Despite these acts of co-operation, D.J. Pretorius was accused of being an undesirable person and sympathetic to the Boer cause. ${ }^{82}$

The cross-border raids by the Boer commandoes into Zululand did not only adversely affect the Afrikaners of Proviso B, ten of whom were eventually convicted as rebels, ${ }^{83}$ but also the local Zulu inhabitants. To replenish their own herds, Boer commandoes targeted and raided cattle belonging to Zulu inhabitants residing just inside Zululand. Such raiding was especially detrimental since rinderpest and lung sickness had not long before decimated large herds of cattle in Zululand - the economic lifeline of the Zulu people. These Boer raids prompted the Zulus to counteract by mounting several raids on Boer farms in the Vryheid district. These counter raids prompted CM and CC Saunders, who was still trying to keep the war away from Zululand, to issue instructions that no armed Zulu parties were to be allowed to cross the border into the Transvaal. ${ }^{84}$ All trade between Zululand and the Vryheid district was also suspended, and no one was allowed to bring any cattle from the Transvaal into Zululand. ${ }^{85}$

This measure brought relative calm and peace to the Transvaal-Zululand borderlands. However, this all changed in March 1901 when the Commander-inChief of the British army, Lord Kitchener, authorised Colonel H. Bottomley of the Imperial Light Horse, to raise a body of men to assist in blockading the TransvaalZululand border. This was considered necessary to prevent Boers from fleeing the scorched earth drives of Major General John French in the south-eastern part of the Transvaal by crossing into Zululand. On top of this, Bottomley was ordered to command and organise the Zulus to drive Boer cattle from the Vryheid district into Zululand. What made these orders disputatious was that Bottomley was allowed to operate independently from the local Zululand magistrates, CM and CC Saunders and the general officer commanding Natal, Major General H.J.T. Hildyard. ${ }^{86}$ What was even more controversial was the self-enrichment clause in Bottomley's orders, which allowed him and his men to keep $65 \%$ of the confiscated cattle, while the Zulu collaborators were to receive $10 \%$ and the British army $25 \%$. These orders, 
which completely side-stepped the civilian administration and infuriated both Saunders and the Natal Government because the inhabitants of Zululand could now be armed and sent without white supervision into the Transvaal to loot Boer stock. In the view of Saunders, these orders completely undermined his authority. ${ }^{87}$

When Bottomley arrived in Zululand on 26 March 1901, he immediately implemented his orders. He appointed Captain Wickham as the military agent at Nkandla and Bernard Cressey at Melmoth. Bottomley then visited both Dinizulu and Zibhebhu and ordered them to arm themselves. Dinizulu responded by organising a group of 1500 men. The orders issued by Bottomley, as expected, posed a serious challenge to the civil administration, especially since several amakosi used the opportunity to raid into the Transvaal. For example, by 4 April 1901, Ngodi and his followers of Nkandla had crossed into the Transvaal and after a skirmish with a Boer commando raided 600 sheep and 500 cattle. Similar raids by Kamba, Zibhebhu, Nongamulana, Sitshitshili, Dinizulu and Mehlokazulu and their men followed so as to secure livestock. ${ }^{88}$ The arrival of Bottomley therefore signalled the arming of the Zulus under white officers so as to raid Boer livestock, and especially Dinizulu became a key player as some of his followers were heavily armed and organised along British military lines. ${ }^{89}$

This new dimension to the war alarmed the Zululand magistrates who tried to regain some semblance of power by forbidding the amakosi and their followers to raid into the Transvaal. These instructions had little impact, and CM and CC Saunders feared that especially the parties under Dinizulu could grow too strong and in the process start posing a threat to the security of the Colony of Natal. Saunders therefore threatened to withdraw all magistrates from Zululand should Bottomley and his agents be allowed to continue with their operations. ${ }^{90}$

Bottomley and his agents were by now a law unto themselves with selfenrichment by way of stock rustling being their sole purpose. When it became more difficult to obtain Boer cattle, the agents started to raid Zulu livestock both in Zululand and in the Vryheid district under the pretext that the animals belonged to Boers and were being hidden by the Zulus. At the same time, to ensure the success of this new dimension in the livestock raiding, Bottomley and his agents abused the legacy of the Zulu Civil War between Cetshwayo and Dinizulu and the latter's distracters of two decades earlier by inciting factions against each other. These actions further served to undermine the authority of the Zululand magistrates and outweighed any possible military gain the raiding could have provided. At another level, as anticipated by the civilian authorities in Zululand, the livestock raids merely served to agitate the Boer forces and, as a result, military activities in the 
Transvaal-Zululand borderlands greatly increased as commandoes set out to regain livestock and to exact revenge. ${ }^{91}$

One of the first Boer retaliations happened in April 1901, when a small commando raided, looted and burned the store of F.S. Mann in the Mahlabatini district. $^{92}$ Several other Boer parties also became active along the now very troublesome border. The largest of these, 500 men under Commandant Scholtz, invaded the Mahlabatini district, capturing livestock in the process. A section of this commando also attacked the magistracy at Mahlabatini, which was manned by members of the Melmoth Field Force, the Zululand Native Police and Magistrate Wheelwright and his court officials. The Boers were eventually driven back by the defenders who had lost four men in the process. ${ }^{93}$ Various other Boer commandoes under Grove, Grobbelaar and Dannhauser likewise became active in Zululand during the time of the Bottomley raids. Crossing the Transvaal-Zululand border, they cut telegraph lines, looted stores and raided cattle to replenish the livestock lost during the raids. ${ }^{94}$ Other Boer residents of the Vryheid district, in an attempt to escape the raiding, crossed the border into Zululand, with their livestock and families in tow, to surrender to either the military or the civilian authorities. The net effect of the activities of Bottomley and his men was that a relatively quiet front had now become a very active one. ${ }^{95}$

The fall-out of the actions by Bottomley and his agents prompted CM and CC Saunders to continue exerting pressure, by means of daily telegrams of complaint, to both Prime Minister A.H. Hime and Governor H.E. McCallum. On some days, such as 9 May 1901, Saunders sent five telegrams outlining the problematic nature of the activities of Bottomley and his agents. ${ }^{96}$ As a result of this constant lobbying, the operations by Bottomley and his agents were not only formally terminated in early June 1901 but also subjected to a commission of enquiry. One outcome of this being the disbandment of the Zulu forces created by Bottomley, that is except for the old enemies, Dinizulu and Zibhebhu, who were allowed to keep small bodies of armed men for defensive purposes. ${ }^{97}$

During the relatively short time period that Bottomley and his agents were active in the borderlands, an estimated 10000 head of Boer cattle and several thousand head of sheep were taken. ${ }^{98}$ Colonel Bottomley then disappeared from the Zululand scene, but not before being appointed a commander of the order of St Michael and St John (CMG) for the service he had rendered. Apart from logistically crippling some Boers and Boer commandoes operating in the Vryheid district, these raids also served to cause bad blood between the Zulus of both the Vryheid district and Zululand and the Boers, for not only were Boer families uprooted from the 
Vryheid district and Zulu families from the borderlands but the economic lifeblood of both communities - livestock - were more so than ever before dragged into the conflict. However, the major legacy of the activities of Bottomley and his agents was the increased military activities in the borderlands. According to Minnaar, these consisted of small parties of Boers who wandered up and down the TransvaalZululand border harassing local inhabitants and badly defended outposts. ${ }^{99}$

The most important of these military activities on the Boer side were those undertaken under General Louis Botha. In September 1901, Botha, in an effort to divert the war from the Transvaal, commenced with an invasion of Natal. En route, his commando defeated, on 17 September 1901, a force under Major Hubert Gough at Blood River Poort. This defeat prompted several actions from the British army. Firstly, all the drifts leading from the Vryheid district into Northern Natal were blocked. Secondly, the three British columns that were pursuing Botha and his commando were strengthened by members of the Natal Volunteer Forces and Zulu soldiers. In Zululand, the fear that the blocking of the drifts leading into Northern Natal would deviate Botha's operations into their direction, prompted the officer commanding of troops stationed at Eshowe, Major H.A. Vowell, to order an officer and 48 men from Melmoth to Fort Prospect and two officers and 60 men of the $5^{\text {th }}$ Division Mounted Infantry from Fort Prospect to Itala. ${ }^{100}$

The British occupation of De Jager's, Stael's, Vant's and Rorke's Drifts as well as the swollen Buffalo River thwarted Botha's plans to invade Northern Natal. He was therefore, as anticipated by Vowell, forced to enter Zululand. ${ }^{101}$ The first contact between the British forces in Zululand and the invading commando took place on 22 September 1901 when the Volunteer Composite Regiment and Botha's commando exchanged fire. During the course of action, two Boers were wounded and a Zulu border guard killed while 1000 head of cattle from the Telezeni and Nkandla areas were rounded up. Botha returned these cattle to the Zulu leaders, apologising at the same time for the attacks by the commandoes making it clear that he had no quarrel with them. Botha also requested the leaders to remain calm and peaceful in their homes. From Nqutu, Botha's commando moved to Babanango where he established his headquarters on the farm Gelykwater. Acting on information from the local Boer commander, Commandant Dannhauser, about the poor fortifications of the military posts at Fort Itala and Nkandla, it was decided to attack these positions. ${ }^{102}$

Contrary to Botha's hopes, the Zulus did not remain neutral and the 300 mounted fusiliers under Major A.J. Chapman at Fort Itala were warned of the presence of the commando. This allowed Chapman the opportunity to strengthen his 
position by means of fortifications and the despatch of an advance party. Fort Itala was attacked by the commando under full moon on 26 September 1901. Despite some determined efforts by the Boers, they were neutralised by the fortifications and the effective use of the available two guns. As a result, the Boer attack petered out. When the commando withdrew, Fort Itala was close to collapse. The British force had manned its defences for 18 hours and had 26 men killed and 59 wounded. Fearing a possible second attack, the British force withdrew to Nkandla. The commando under Botha had also suffered - a number of men were killed and at least a hundred were wounded. ${ }^{103}$

Unlike Fort Itala, the British position at Fort Prospect was well chosen and fortified and defended by 30 men of the Fifth Division Mounted Infantry Battalion, 50 men of the Durham Company of Militia Artillery, a party of Zululand Native Police and a maxim machine gun under Captain C.A. Rowley of the Dorsetshire Regiment. On the Boer side, the assault was headed by the Carolina and Ermelo Commandoes under General J.C. Emmett and Commandant J.N.H. Grobler. Under the cover of darkness and thick mist, it was decided to launch an attack from the northwest. The Boer attack came to within 20 metres of the fortifications but they were driven back. When the mist lifted, the Boers withdrew as they and their horses came under heavy fire. Emmett and Grobler, however, decided to launch a second attack - this time from the southwest. Again, the Boer attack was nullified with Sergeant Gumbi and his 13 men of the Zululand Native Police playing a vital role. ${ }^{104}$ The two failed attacks as well as the lack of cover brought a halt to the Boer offensive, and the commandoes withdrew. In terms of casualties, the British had lost one man while nine were wounded, while on the Boer side two men were wounded. ${ }^{105}$

With the Boer attacks at Fort Itala and Fort Prospect foiled, the invasion threat moved south to the drifts of the lower Tugela River. Immediate precautions were taken by the British army to prevent the further advance of Botha's commando. Troops from Glencoe, Ladysmith and Pietermaritzburg were sent to Eshowe, while reinforcements were forwarded from Harrismith. At the same time, Natal volunteers from Greytown were ordered to secure the drifts of the lower Tugela River. ${ }^{106}$ However, the commando, fearing that its escape route back into the Transvaal would be cut off, remained in the Fort Prospect area. The next clash therefore took place near Fort Prospect when a convoy of 31 wagons bound for the relieving column under Major General Bruce Hamilton was overrun. Of the eight Zululand Native Police escorting the convoy, six were killed while the white officer in charge was captured. This was a real windfall for the hard-pressed Boers as the wagons contained supplies of food and clothing. ${ }^{107}$ 
The capture of the wagon train led the British to fear that Eshowe, Melmoth and Nkandla were in danger and therefore more troops were deployed in Zululand. At a local level, Major H.A. Vowell ordered the outlying detachment from Mthonjaneni to Melmoth to strengthen the town. However, Botha, with his supplies replenished, decided to withdraw to the Transvaal before his line of retreat was cut off, and by the end of September, he began moving north. The invasion of Zululand was over, and only splinter groups of Boers kept operating in the borderlands. ${ }^{108}$

In February 1902, five months after his initial invasion of Zululand, Louis Botha and his commando returned to the Vryheid district and this immediately led to renewed fears that Zululand would again be invaded. ${ }^{109}$ In an effort to apprehend Botha, Major General Bruce Hamilton arrived in Vryheid on 5 March 1902 with a large force. He immediately called on Dinizulu to supply him with 250 men to assist in the rounding up of Boer livestock. With CC and CM Charles Saunders at last granting permission, the force led by Ndabuko, Madubeko and Madakavana was taken to Hamilton's camp. On arrival, the Zulu force, armed with rifles of all sorts and assegais, had swollen to beyond 250. The reason for this was that they were joined by members of the eBaqulusi under Sikhobobo who, despite residing in the Vryheid district, viewed themselves as followers of Dinizulu. The instructions issued to the Zulus were clear - they had to proceed alongside the British and to take prisoner any Boer commando member they intercepted, as well as to round up all Boer livestock. ${ }^{110}$

This step by the military, which not only allowed for joint operations between the British army and the Zulus - be they Natal or Transvaal subjects - did not only break down national boundaries but also had, for the first time, the blessing of the head of the civilian authorities in Zululand. This signalled the final death knell of the "white man's war" policy as implemented along the Transvaal-Zululand border. Therefore, what started with the British army employing Zulus in an auxiliary capacity ${ }^{111}$ had evolved to where, two years on, Zulus were fully involved in all spheres of war in the borderlands. On the side of the Natal authorities, pragmatism had replaced the racial delineation, and the Zulus and Zulu leadership in both Zululand and the Transvaal were now openly involved in the war without impediment. This official involvement of the Zulu in a fighting capacity brought a new dimension to the war in the Transvaal-Zululand borderlands which placed the remaining Boer commandoes in this area under even more pressure. From their side, the Zulus must have been happy to become involved in the war in a formal fighting capacity for, like Africans in other parts of Natal, they had hoped that their loyalty would be rewarded with political power and economic benefits. Furthermore, for the 
Zulus it was an ideal opportunity to avenge issues of war, land and cattle that stretched back to the arrival of the Great Trek in the 1830s up to the creation of the New Republic in 1884.

The cattle-rustling operation by the combined British-Zulu force was generally successful and netted hundreds of head of cattle. On the completion of it, Dinizulu's men returned to Zululand via Vryheid. However, Sikhobobo and his followers' participation, as Transvaal subjects, placed them in a very difficult position and they could not return home. Consequently, they were accommodated in the railway station buildings in Vryheid under the protection of Major General Hamilton and Magistrate A.J. Shepstone. As expected, the involvement of Sikhobobo in the operations infuriated Louis Botha. As a result, he ordered the Vryheid and Utrecht Commandoes to punish Sikhobobo and his followers for their involvement. This the commandoes did and in the process they burned down homesteads and captured 3800 head of cattle, sheep and goats, which were driven to Holkrantz. ${ }^{112}$ These actions by the commando set the tone for what followed and which constituted a turning point in the war, not only in the borderlands but also in general. On the evening of 6 May 1901, Sikhobobo, with a party of 300 men, left Vryheid to take up the challenge posed by Field Cornet Jan (Mes) Potgieter to try to get back their cattle. However, as it emerged later, the real aim of Sikhobobo was to attack the laager at Holkrantz. ${ }^{113}$ On arrival, a council of war was held and Sikhobobo and his men started their attack at 04:00. During the ensuing action, 56 Boers were killed and three were taken prisoner while all the cattle in the camp were driven off. The Boers in return managed to kill 52 Zulus and wound $48 .{ }^{114}$ With this attack by Zulus, who were Transvaal subjects, the final vestiges of a "white man's war" along the borderlands was buried.

Since this battle took place shortly before the end of the Anglo-Boer War and because it constituted a completed change in the dynamics of the war with an organised African military group successfully attacking a Boer commando, much controversy arose. A British commission of enquiry, under Lieutenant Colonel G.A. Mills, concluded that the Boers were attacked by the Zulus because the Boers had mistreated the Zulu and had thus brought this onto themselves. ${ }^{115}$ However, this is but partially true as Sikhobobo and his followers were under British command and protection and were, according to Maphalala, carrying out orders rather than seeking revenge. ${ }^{116}$ Despite the conflicting evidence and interpretations, what the Battle of Holkrantz did signal to the Boer officers, then discussing peace, was that an additional threat had arisen along the Transvaal-Zululand border, namely the exhibition of military agency by the Zulu inhabitants. To the Boer leaders, the message was clear - they had to seek peace. ${ }^{117}$ 
With peace negotiations under way, Lord Kitchener, in a telegram sent on 19 May 1902 to all magistrates in Zululand and to Boer commandoes in the borderlands, instructed that the latter were to be immune from attack, pending further orders. That was to be the case as long as these commandoes refrained from any aggressive action. ${ }^{118}$ This instruction brought to a close all military operations in the Transvaal-Zululand borderlands.

Peace came about on 31 May 1902. In 1903, the Vryheid district of the Transvaal was incorporated into the Colony of Natal and as a result, the geopolitical border with Zululand disappeared. ${ }^{119}$ While concerted reconciliation efforts took place between the white protagonists and economic support structures were initiated, the Zulu inhabitants of the Vryheid district who had supported the British war effort and who had even claimed some farms in the district, including that of Louis Botha, ${ }^{120}$ were again reduced to farm labourers. Leaders like Sikhobobo who were viewed by the local white inhabitants as being too militant were replaced with more moderate amakosi. ${ }^{121}$ The experience on the other side of the borderlands was hardly different. In the wake of the war, the land commission of 1902 opened up large areas of Zululand to white settlement. ${ }^{122}$

The low intensity warfare in the borderlands of the Transvaal and Zululand lasted for the duration of the conflict and transcended the geography of the region involving all the inhabitants of the area in some way or another. Apart from the pitched battles fought at Itala and Fort Prospect, the conflict for the most part amounted to attacks and raids on homesteads, farms, outlying military and government posts and isolated shops. However, one aspect that was central to the attacks and raids was that of livestock and especially cattle. As the economic lifeblood of most of the inhabitants of the borderlands, gaining and regaining cattle at times became the primary objective of various cross-border actions, reducing the actual war to a secondary objective. However, the war in the borderlands of the Transvaal and Zululand also served to cross borders of the mind. The Zulu people, as the demographic majority of the borderlands, were initially, in theory at least, excluded from the war. Nevertheless, as the war progressed their involvement systematically evolved from being bystanders to a "white man's war" into fullfledged participation in all aspects of the conflict culminating in the Battle of Holkrantz where Zulus, as Transvaal subjects, defeated a local commando. In so doing, a major racial border was momentarily crossed. However, the end of the war soon made this border disappear as the Transvaal-Zululand borderlands were absorbed into the Colony of Natal, which not only returned all the Zulu inhabitants to their pre-war status but also opened up large tracts of Zululand to white 
settlement. In so doing, the historic processes that birthed the Transvaal-Zululand border came to a head with the Colony of Natal emerging as the ultimate conqueror of the borderlands.

\section{Endnotes}

${ }^{1}$ Maphalala, SJ. “The participation of Zulus in the Anglo-Boer War, 1899-1902”. MA thesis, University of Zululand, 1978; Maphalala, SJ. "The Zulus and the Boer War”. History Today 50/1. January 2000. 46-51.

2 Minnaar, A de V. "Zululand and the Anglo-Boer War (1899-1902)". Military History Journal 8/1. June 1989. 1-11. <http://samilitaryhistory.org> Accessed on 13 December 2010.

${ }^{3}$ See for example, Pakenham, T. Die Boereoorlog. Johannesburg: Jonathan Ball, 1979; Amery, LS (ed), The Times history of the war in South Africa 18991902, 7 volumes. London: Samson Low, Marston \& Co, 1900-1909; Breytenbach, JH. Die geskiedenis van die Tweede Vryheidsoorlog in SuidAfrika, 1899-1902, 5 volumes. Pretoria: Government Printer, 1969-1983; Farwell, B. The Great Boer War. London: WW Norton, 1990.

4 Lunsford, AA \& Ouzgane, L. Crossing borderlands: Composition and postcolonial studies. Pittsburgh, PA, University of Pittsburgh Press, 2004.

${ }^{5}$ Zibhebhu had a strong independent streak and was not always completely loyal to Cetshwayo. He did, however, despite being opposed to it, serve with distinction in the Anglo-Zulu War. After the conflict he became one of the 13 independent leaders appointed by the British - a position he kept up to and after the restoration of Cetshwayo. Brookes, EH \& Webb, C de B. A history of Natal. Pietermaritzburg: University of Natal Press, 1987, 98-100, 137.

${ }^{6}$ Laband, J \& Thompson, P. “The reduction of Zululand”. In Duminy, A \& Guest, B (eds), Natal and Zululand from earliest times to 1910 - a new history, Pietermaritzburg: University of Natal Press, 1989, 212-213; Laband, J. Rope of sand - the rise and fall of the Zulu Kingdom in the nineteenth century. Johannesburg: Jonathan Ball, 1995, 367-378; Guy, J. The destruction of the Zulu kingdom. Johannesburg: Ravan, 1982, 3-105.

${ }^{7}$ Laband \& Thompson op. cit., pp. 212-213; Maphalala, "The Zulus and the Boer War” op. cit., pp. 46-47.

${ }^{8}$ Dinizulu in 1888 ran foul of some of the new laws brought about by annexation and was accused of revolting. He and several followers were sentenced to 10 years' imprisonment on St Helena and only returned to Zululand in 1898 as a "Government Induna, with a salary of $£ 500$ plus a house". For all intents and purposes he was from then on - like his nemesis Zibhebhu, who was on a pension of $£ 240$ per annum - a functionary of the Natal and British authorities. Brookes \& Webb op. cit., pp. 146, 153-154, 185-186; Maphalala, "The Zulus and the Boer War" op. cit., pp. 46-51; Laband op. cit., pp. 343-346.

${ }^{9}$ Laband \& Thompson op. cit., pp. 215-216. 
${ }^{10}$ Brookes \& Webb op. cit., pp. 185-186; Laband op. cit., pp. 367-377.

${ }^{11}$ Maphalala, “The Zulus and the Boer War” op. cit., p. 48.

${ }^{12}$ Brookes \& Webb op. cit., pp. 185-186.

${ }^{13}$ Coghlan, MS. "The Natal volunteers in the Anglo-Boer War, September 1899 to July 1902: Reality and perception”. Phd dissertation, Univeristy of Natal, 2000, passim.

${ }^{14}$ Maphalala, "The participation of Zulus ...” op. cit., p. 35; Warwick, P. Black people and the South African War 1899-1902. Johannesburg: Raven, 1983, $6,15$.

15 Pretorius, F. Kommandolewe tydens die Anglo-Boereoorlog 1899-1902. Cape Town: Human \& Rousseau, 1999, 299.

${ }^{16}$ Maphalala, “The Zulus and the Boer War” op. cit., pp. 51, 48.

${ }^{17}$ Pretorius op. cit., pp. 282-322.

18 Pietermaritzburg Archive Repository (hereafter PAR), Government House (hereafter GH) 1040: Minute paper Prime Minister AH Hime to Governor W Hely-Hutchinson, 13 February 1900.

${ }^{19}$ PAR, GH 1040: Minute paper Prime Minister AH Hime to Governor W HelyHutchinson, 14 February 1900.

${ }^{20}$ Warwick op. cit., pp. 77-79.

21 PAR, Attorney General's Office (hereafter AGO) I/8/67: Minute paper by Attorney-General $\mathrm{H}$ Bale on African involvement in the war, 19 October 1899.

${ }^{22}$ Warwick op. cit., p. 76.

${ }^{23}$ Times of Natal, 28 August 1899.

${ }^{24}$ Natal Witness, 18 September 1899.

${ }^{25}$ PAR, Colonial Secretaries Office (hereafter CSO) 2580: Letter Prime Minister AH Hime to magistrate, 9 September 1899.

${ }^{26}$ Lambert, J. "Loyalty its own reward: The South African War experiences of Natal's 'Loyal' Africans”. In Cuthbertson, G, Grundlingh, AM \& Suttie, AL (eds), Writing a wider war: Rethinking gender, race and identity in the South African War, 1899-1902, Athens: Ohio University Press, 2002, 115135; Lambert, J. Betrayed trust: Africans and the state in Colonial Natal. Pietermaritzburg: University of Natal Press, 1995, passim.

${ }^{27}$ PAR, CSO 2581: Report Magistrate P Hugo, Dundee, 28 September 1899; Report Magistrate JO Jackson, Newcastle, 16 September 1899.

${ }^{28}$ PAR, Secretary of Native Affairs (hereafter SNA) I/4/6: Letter Magistrate TR Bennett, Klip River district, 13 September 1899.

${ }^{29}$ Maphalala, "The Zulus and the Boer War" op. cit., p. 49.

${ }^{30}$ Hobsbawm, E. The age of capital 1845-1975. London: Abacus, 1975, 144.

${ }^{31}$ Maphalala, “The Zulus and the Boer War” op. cit., p. 49.

${ }^{32}$ PAR, SNA 1/4/7: Confidential papers and magisterial reports, 1899-1902.

${ }^{33}$ PAR, SNA I/7/40: Report by native intelligence officer No. 1, 14 December 1899; I/4/8: Report by native intelligence officer No. 1, 10 February 1900; I/7/40: Report by native intelligence officer No. 1, 14 December 1899; I/4/6: Report by native intelligence officer No. 2, 9 December 1899; I/7/40: Report by 
native intelligence officer No. 1, 14 December 1899; I/4/6: Two reports by Africans, 23 November 1899.

34 PAR, CSO 1639: Deposition by Manlinzela Ka Ngombane, 15 January 1900; CSO 2584: Report Magistrate T Maxwell, Melmoth, 28 November 1899; PAR, SNA I/4/7: Letter Magistrate $T$ Maxwell, Melmoth, to Chief Magistrate CJR Saunders, 20 October 1899.

35 Spies, SB. Methods of barbarism? Roberts and Kitchener and civilians in the Boer Republics, January 1900 - May 1902. Cape Town: Human \& Rousseau, 1977, 155; Minnaar op. cit., pp. 1-2.

${ }^{36}$ Amery, Vol. III op. cit., pp. 138-139; Minnaar op. cit., p. 2.

${ }^{37}$ Maphalala, “The participation of Zulus ...” op. cit., p. 21.

${ }^{38}$ PAR, SNA 1/4/7: Confidential papers and magisterial reports CR 163/1899, 19 October 1899.

${ }^{39}$ PAR, AGO I/7/40: Extract confidential report Magistrate T Maxwell, Melmoth, 18 October 1899.

${ }^{40}$ Pretorius op. cit., p. 301.

${ }^{41}$ Minnaar op. cit., p. 2.

42 PAR, AGO I/7/4: Regina vs. TP Lezar, pp. 71-74; Natal Witness, 12 October 1900.

${ }^{43}$ PAR, CSO 2876: Invasion Losses Enquiry Commission claim by AS Eksteen, 6 October 1902.

${ }^{44}$ PAR, AGO I/7/25: Rex vs. TR Boshoff, pp. 550-555; AGO I/7/5: Regina vs. G Adendorff, pp. 91-93; AGO I/7/6: Regina vs. WH (snr), WH (jnr) and IJ Boshoff, pp. 128-129.

${ }^{45}$ OE Prozesky private collection, Diary of JJA Prozesky: Diary entry, 4 December 1899, p. 101.

${ }^{46}$ Breytenbach, JH. Die geskiedenis van die Tweede Vryheidsoorlog in Suid-Afrika, 1899-1902. Vol. III: Die stryd in Natal Jan-Feb 1900. Pretoria: Government Printer, 1973, 377.

${ }^{47}$ Breytenbach op. cit., pp. 378-379.

48 PAR, AGO I/7/25: Rex vs. JC and JN Boshoff, pp. 519-520; Rex vs. WD Adendorff, pp. 491-492; AGO I/7/24: Rex vs. J van Reenen, pp. 461-464; Natal Witness, 22 March 1901; AGO I/7/25: Rex vs. JC and JN Boshoff, pp. 519-520.

${ }^{49}$ PAR, AGO I/7/30: Rex vs. JP van der Westhuyzen, pp. 690-695; Natal Witness, 1 November 1901.

${ }^{50}$ OE Prozesky private collection, Diary of JJA Prozesky: Diary entries, 13 January 1900, pp. 120-121; 23 January 1900, p. 123.

${ }^{51}$ PAR, AGO I/7/7: Regina vs. CL, PJ and DR de Wet, pp. 131-133; Regina vs. JJ, NJ (jnr) and DIP Degenaar, pp. 135-137; Regina vs. AM Cronjé (snr), pp. 153-154; I/7/30: Regina vs. CJS Hattingh, pp. 682-683. The fear of being convicted as rebels was not unfounded, as after the Boer retreat, 120 white inhabitants of Newcastle were convicted of high treason. See Wassermann, JM. Caught between the Empire and the Republics - Natal Afrikaners and the Anglo-Boer War. Saarbrücken: VDM Verlag, 2009, 208. 
${ }^{52}$ Wassermann op. cit., p. 80.

${ }^{53}$ Minnaar op. cit., pp. 2-3.

${ }^{54}$ Ibid., p. 3.

55 Ibid., pp. 2-4. At times during the war, commandoes executed Africans working as spies for the British army. Pretorius op. cit., pp. 289-293.

${ }^{56}$ PAR, AGO I/7/40: Depositions by B Cressey and KJD Ripley, 6 December 1899.

57 PAR, CSO 1639: Deposition by Manlinzela Ka Ngombane, 15 January 1900; CSO 2584: Report Magistrate T Maxwell, Melmoth, 28 November 1899.

${ }^{58}$ PAR, AGO I/7/40: Depositions by B Cressey and KJD Ripley, 6 December 1899.

59 PAR, AGO I/7/42: Depositions by TW Cooper and RJ Hutchinson, 17 March 1900.

${ }^{60}$ Minnaar op. cit., p. 3; Warwick op. cit., p. 83.

${ }^{61}$ Amery, Vol III op. cit., pp. 100, 329-330.

${ }^{62}$ Wassermann op. cit., pp. 45-46.

${ }^{63}$ PAR, AGO I/7/22: Rex vs. PJ de Waal, pp. 372-373; I/7/23: Rex vs. DC Uys, p. 413.

${ }^{64}$ Public Record Office (hereafter PRO), Colonial Office (hereafter CO) 179/210: Deposition by Matabata Ka Nhlebo before Magistrate JL Knight, 14 February 1900.

${ }^{65}$ Warwick op. cit., p. 85.

${ }^{66}$ PAR, SNA 1/4/7: Confidential papers and magisterial reports CR 126/1900 and CR 140/1900, 19 February 1900; Minnaar op. cit., p. 4.

${ }^{67}$ Warwick op. cit., p. 85.

68 Ploeger, J. Die lotgevalle van die burgerlike bevolking gedurende die AngloBoereoorlog, 1899-1902. Deel IV. Pretoria: National Archives, 1990, 27:15.

${ }^{69}$ Warwick op. cit., p. 87.

${ }^{70}$ PAR, SNA 1/4/7: Confidential papers and magisterial reports CR 10/1900, 1 January 1900; Minnaar op. cit., p. 4.

${ }^{71}$ NAR, Staff Officer Prisoners of War, Natal (hereafter SOP) 7: Letter Maj. TAB Forster to Comdt., Durban, 9 March 1901.

72 Nasson, B. "Black communities in Natal and the Cape". In Omissi, D \& Thompson, AS (eds), The impact of the South African War, London: Palgrave, 2002, 38-39.

${ }^{73}$ Ploeger op. cit., pp. 20:6-20:12.

${ }^{74}$ Brookes \& Webb op. cit., pp. 57-61; Maphalala, “The Zulus and the Boer War” op. cit., pp. 47-48. AJ was the son of Theophilus Shepstone, who was the administrator of the Transvaal from 1877 to 1880 when it was annexed by Britain, and also the father of the "location policy", which created "native reserves" in the Colony of Natal.

${ }^{75}$ Maphalala, "The Zulus and the Boer War” op. cit., pp. 48-49.

${ }^{76}$ DAR, Magistrate of Eshowe (hereafter 1/ESH) 3/2/4: Notice under Martial Law, Magistrate A Boast, Eshowe, 11 October 1901.

${ }^{77}$ PAR, Magistrate of Mahlabatini (hereafter 1/ MBT) 3/2/2: Letter Magistrate CA Wheelwright, Mahlabatini, to CM and CC CR Saunders, 26 November 1901. 
${ }^{78}$ PAR, Magistrate of Nongoma (hereafter 1/NGA) 3/2/7: Letter CM and CC CR Saunders to Magistrate A Boast Eshowe, 14 April 1902.

${ }^{79}$ PAR, Zululand Administration (hereafter ZA) 33: Telegram Officer Commanding Natal Maj. Gen. HJT Hildyard to magistrate Nqutu, 9 October 1900.

${ }^{80}$ PAR, ZA 33: Secret letter CM and CC CR Saunders to Prime Minister AH Hime, 11 February 1901.

81 DAR, Magistrate of Melmoth (hereafter 1/MEL): Letters DJ Pretorius to Magistrate A Hulley, Melmoth, 4 February 1902 and 19 February 1902; 1/MEL: Letters AL Pretorius to Magistrate A Hulley, Melmoth, 5 February 1901 and 19 February 1901.

${ }^{82}$ PAR, ZA 33: Documents pertaining to the investigation of the cattle belonging to S Loffler, January 1900.

${ }^{83}$ Wassermann op. cit., p. 208.

${ }^{84}$ Warwick op. cit., p. 87.

${ }^{85}$ DAR, 1/ESH 3/2/4: Telegram CM and CC CR Saunders to Magistrate A Boast, Eshowe, 3 December 1900.

${ }^{86}$ PAR, SNA 1/6/25: Papers relating to the actions of Col. H Bottomley, 1901-1902; DAR, 1/MEL 3/2/8: Circular from CM and CC CR Saunders, 6 July 1901.

${ }^{87}$ DAR, 1/MEL 3/2/2: Circular from CM and CC CR Saunders, 6 July 1901.

${ }^{88}$ Minnaar op. cit., p. 5; Maphalala, “The participation of Zulus ...” op. cit., pp. 5759; Maphalala, "The Zulus and the Boer War" op. cit., p. 50.

${ }^{89}$ Maphalala, “The Zulus and the Boer War” op. cit., p. 50.

${ }^{90}$ PAR, SNA 1/6/25: Papers relating to the actions of Col. H Bottomley, p. 15, 1901-1902.

91 PAR, SNA 1/6/25: Papers relating to the actions of Col. H Bottomley, p. 15, 1901-1902.

92 Minnaar op. cit., pp. 5-6; Maphalala, “The participation of Zulus ...” op. cit., p. 71.

93 DAR, 1/MEL 3/2/8: Correspondence from Magistrate CA Wheelwright, Mahlabatini, 28 April 1901; Minnaar op. cit., p. 6.

94 PAR, CSO 2592: Telegrams exchanged between CM and CC CR Saunders and the Prime Minister and Governor of Natal, April and May 1901.

95 Wassermann op. cit., p. 262.

96 PAR, CSO 2592: Telegrams exchanged between CM and CC CR Saunders and the Prime Minister and Governor of Natal, 23 April 1901, 4 May 1901, 5 May 1901, 6 May 1901, 7 May 1901, 9 May 1901 and 10 May 1901.

97 PAR, SNA 1/6/25: Report of evidence given by CM and CC CR Saunders, p. 32.

${ }^{98}$ Warwick op. cit., pp. 89-90.

99 Minnaar op. cit., p. 6.

100 Moore, DM. General Louis Botha's second expedition to Natal during the Anglo-Boer War, September-October 1901. Cape Town: Historical Publication Society, 1979, 37-40; Pakenham op. cit., pp. 552-554.

101 Moore op. cit., pp. 36-43; Carter CM. "Itala - monument to valour”. Military History Journal 2/1. June 1971. 1-6. <http://samilitaryhistory.org> Accessed on 13 December 2010. 
102 Moore op. cit., pp. 37-39; Amery, Volume V op. cit., pp. 344-345.

103 Moore op. cit., pp. 40-45; Pakenham op. cit., pp. 552-554.

104 Amery, Volume V op. cit., pp. 348-349.

105 Moore op. cit., pp. 70-71; Carter op. cit., pp. 1-6.

106 Moore op. cit., p. 76.

107 Ibid., pp. 77-80; Amery, Volume V op. cit., pp. 349-350.

${ }^{108}$ Moore op. cit., pp. 78-80.

109 PAR, ZA 33: Message to the Officer Commanding troops in Zululand, Maj. HA Vowell, 1 March 1902.

110 PAR, SNA 1/6/25: Miscellaneous papers regarding Col. H Bottomley’s actions, 1901-1902.

111 Warwick op. cit., pp. 6-15.

112 PAR, CSO 2953: Lt. Col. GA Mills - Report on the causes which led to the illfeeling between the Boers and the Zulus under Sikobobo at Holkrantz on 6 May 1902.

113 PAR, GH 1304: Natal copies of annexure to confidential dispatches to the Secretary of State for the Colonies, 5-16 October 1902.

114 War Museum of the Boer Republics (hereafter WM), Accessions 2057/5 and 5123/1; Pakenham op. cit., p. 589.

115 PAR, CSO 2953: Lt. Col. GA Mills - Report on the causes which led to the illfeeling between the Boers and the Zulu under Sikobobo at Holkrantz on 6 May 1902.

116 Maphalala, SJ. “The murder at Holkrantz (Mthashana) 6th May, 1902”. Historia 22/1. May 1977. passim.

117 Pakenham op. cit., p. 589.

118 PAR, ZA 33: Telegram Capt CM Maynard Staff Officer troops in Zululand to Zululand magistrates, 19 May 1902.

119 Brookes \& Webb op. cit., pp. 210-211; Wassermann op. cit., pp. 442-444.

120 Pretorius op. cit., p. 299.

121 Maphalala, The Zulu and the Boer War op. cit., p. 50

122 Brookes \& Webb op. cit., pp. 186-188; Laband op. cit., pp. 424-436. 